\title{
THE EFFECTS OF SORGHUM AND COWPEA GENOTYPE AND SORGHUM SOWING DENSITY IN AN INTERCROP SYSTEM
}

\author{
By M. A. DE QUEIROZ† and N. W. GALWEY \\ Department of Applied Biology, University of Cambridge, \\ Pembroke Street, Cambridge CB2 3DX, England \\ (Accepted 18 November 1986)
}

\begin{abstract}
SUMMARY
Five diverse sorghum genotypes were sown at sole crop density and at intercrop density without cowpea and with two contrasting cowpea genotypes, in the post-rainy season at Hyderabad, India. The interaction of sorghum genotype with sowing density was significant for sorghum dry fodder and grain yield, but the interaction of sorghum genotype with cowpea was not, because of compensation between yield components. The likely response of sorghum genotypes to intercropping can therefore be assessed initially from the performance of low density sole crops, followed by assessment in the presence of a single standard cowpea variety.

The cowpea genotypes were affected by the presence of sorghum but not by the sorghum genotype. This suggests that the effect on the cowpea can be ignored when selecting a sorghum genotype for intercropping, and that a cowpea genotype for intercropping can be selected in the presence of a single sorghum genotype. However, these conclusions are unlikely to apply to rainy season sowings, when sorghum dominates the intercrop more completely.
\end{abstract}

M. A. de Queiroz y N. W. Galwey: Efectos del genotipo de sorgo y caupi y densidad de siembra del sorgo en un sistema de cultivo intercalado.

\section{RESUMEN}

Se sembraron cinco genotipos variados de sorgo con densidades de cultivo único y de cultivo intercalado sin caupí y con dos genotipos de caupi contrastantes, en la estación posterior a las lluvias en Hyderabad, India. La interacción del genotipo de sorgo con la densidad de siembra fue significativa para el rendimiento de forraje seco y de grano de sorgo, pero la interacción de genotipo de sorgo con caupí no lo fue, debido a la compensación entre los componentes del rendimiento. La respuesta probable de los genotipos de sorgo al cultivo intercalado puede, por lo tanto, ser evaluada inicialmente del resultado del cultivo único de baja de densidad, seguido por la evaluación en la presencia de una sola variedad estándar de caupí.

Los genotipos de caupí fueron afectados por la presencia del sorgo, pero no por el genotipo de sorgo. Esto sugiere que el efecto sobre el caupí puede ser ignorado al seleccionar un genotipo de sorgo para el cultivo intercalado, y que un genotipo de caupí para el cultivo intercalado puede ser seleccionado en la presencia de un solo genotipo de sorgo. No obstante, no es probable que estas conclusiones se apliquen a las siembras en la estación de lluvia, cuando el sorgo domina más completamente el cultivo intercalado.

\section{INTRODUCTION}

The response of sorghum genotypes to intercropping with cowpea, and their effect on the associated cowpea, is largely determined by morphological and developmental aspects of the sorghum plant, many of which can be determined in a sole crop (Galwey et al., 1986). Moreover sorghum genotype $X$ environment interactions in intercrop are related to those found in sole sorghum

† Present address: CPATSA/EMBRAPA, Caixa Postal 23, 56300 Petrolina (PE), Brazil. 
so that the effect of sorghum genotypes on the associated cowpea could perhaps be assessed in a single environment (de Quieroz, 1984). These findings were based on a comparison of sole cropping with intercropping with a single standard cowpea genotype in order to study a diversity of sorghum genotypes. This meant that the effects of the cowpea were confounded with those of sowing density, and that it was not possible to test whether particular cowpea genotypes affected, or were affected by, the sorghum genotypes in particular ways. Such interactions, if they occurred, would have important implications in the breeding of sorghum genotypes for intercropping, greatly increasing the work required. The interactions between genotype and sowing density were therefore studied using two contrasting cowpea genotypes and a number of diverse sorghum genotypes.

\section{MATERIALS AND METHODS}

The experiment was conducted at the International Crops Research Institute for the Semi-Arid Tropics (ICRISAT), Hyderabad, India on a deep red soil with good drainage, at the end of the post-rainy season of 1982. The rainfall was below normal, and was concentrated entirely in the thirteenth week of the season. Maximum temperatures and sunshine hours were above their normal levels.

The sorghum varieties used were the inbred line S1006, the inbred dwarf variety $2219 \mathrm{~B}$, the hybrid varieties CSH 5 and CSH 6, and the Ethiopian landrace E 35-1. The cowpea varieties were C 152, selected by the Indian Agricultural Research Institute, which has a semi-erect growth habit and flowers about 45 days after sowing, and GFC 4 , a fodder cowpea selected by Gujarat Agricultural University, India, with a more spreading habit and later maturity. All plots were sown with a seeder in $45 \mathrm{~cm}$ rows. The sorghum was thinned to a within-row spacing of $12 \mathrm{~cm}$, in order to achieve the recommended density of 18 plants $\mathrm{m}^{-2}$ for the sole crop. The cowpea was unthinned, the seed rate being intended to give about the recommended density of 30 plants $\mathrm{m}^{-2}$ for the sole crop. The intercrop plots were sown in an arrangement of one row of sorghum to two rows of cowpea, giving plant densities in a replacement series (De Wit, 1960) of one third sorghum and two thirds cowpea.

The sorghum genotypes were grown in four cropping systems, namely as sole sorghum, as intercrops with cowpea C 152, as intercrops with cowpea GFC 4, and as a sole crop but at intercrop density, i.e. one third of sole crop density. A split-plot design was used in which the sorghum genotypes were allocated to the main plots and the cropping systems to the sub-plots. Sole crop cowpea was included in additional main plots. The main plots were arranged in randomized complete blocks, in three replications.

The dimensions of each sub-plot were $3.6 \times 9 \mathrm{~m}$ for sole crops and $4.5 \times$ $9 \mathrm{~m}$ for intercrops. The central $6 \mathrm{~m}$ of the four central rows of the sole crop plots were harvested, giving an area of $10.8 \mathrm{~m}^{2}$. In the intercrop plots the two 
central sorghum rows plus the two central cowpea rows were harvested, and yields per unit area were adjusted to the correct 1 sorghum:2 cowpea proportions. Preceding the experiment the field had been sown with a uniform cover crop of fodder maize. All the plots received a basal application of $\mathrm{P}_{2} \mathrm{O}_{5}$ at $60 \mathrm{~kg} \mathrm{ha}^{-1}$, and the sorghum was top-dressed with $80 \mathrm{~kg} \mathrm{~N} \mathrm{ha}^{-1}$ in a single application three weeks after emergence. Six insecticidal applications were made to the sorghum, providing intensive protection, and a single insecticide application was made to the cowpea. The experiment was weeded by hand when necessary, and was sprinkle-irrigated at five-day intervals. Thus the overall level of inputs was rather higher than would be used by many growers.

The sorghum canopy height, the width of the plant canopy measured perpendicular to the direction of the row and the percentage of incident light transmitted through the canopy were recorded at full sorghum canopy expansion, i.e. 50 days after eme ${ }^{\circ}$ rence, in the treatments sown at intercrop density. Sorghum and cowpea dry fodder and grain yield and grain yield components were measured at maturity in all treatments. This limited set of measurements was considered adequate for the purposes of this experiment since the growth of sorghum when intercropped with cowpea had already been studied in detail in previous experiments (Galwey et al., 1986).

\section{Statistical methods}

The degrees of freedom for cropping systems were partitioned into orthogonal contrasts in order to determine whether (a) the effect of intercrop density differed on average from that of sole crop density; (b) the effect of intercropping differed on average from that of intercrop density without cowpea; and (c) the effect of cowpea C 152 differed from that of GFC 4. The coefficients for these comparisons are shown in Table 1.

The effect of each contrast is given by:

$$
\Sigma \mathrm{k}_{\mathrm{i}} \overline{\mathrm{x}}_{\mathrm{i}}
$$

where $k_{i}$ is the ith coefficient of the contrast and $\bar{x}_{i}$ the mean of all observations on the ith cropping system. The sum of squares for each contrast is given by:

$$
\left(\Sigma \mathrm{k}_{\mathrm{i}} \overline{\mathrm{x}}_{\mathrm{i}}\right)^{2} / \mathrm{sr} \Sigma \mathrm{k}_{\mathrm{i}}^{2}
$$

where $s=5$, the number of sorghum genotypes, and $r=3$, the number of replications. Each contrast has one degree of freedom (Ridgman, 1975).

\section{Table 1. Coefficients for density and genotype comparisons}

$\begin{array}{lcccc} & \begin{array}{c}\text { Sole crop } \\ \text { density }\end{array} & \begin{array}{c}\text { Intercrop density } \\ \text { without cowpea }\end{array} & \begin{array}{c}\text { Intercrop density } \\ \text { with C 152 }\end{array} & \begin{array}{c}\text { Intercrop density } \\ \text { with GFC 4 }\end{array} \\ \text { (a) Density } & +3 & -1 & -1 & -1 \\ \text { (b) Cowpea presence vs absence } & 0 & +2 & -1 & -1 \\ \text { (c) Cowpea genotype } & 0 & 0 & -1 & +1\end{array}$


The density contrast was omitted for the variables not measured at sole crop density. This analysis may not be valid for the comparison between high and low density because of heterogeneity of residual variances (de Queiroz, 1984), in which case the analysis of ratios between low density and high density could be used. However, the split-plot analysis is likely to be valid for comparisons of treatments with the same sowing density, which are the most important contrasts in the present investigation. The cropping system $X$ sorghum genotype interaction was divided into components for each contrast in order to test whether the contrast effects varied from genotype to genotype.

The effects of sole crop cowpea compared with the intercrop and of cowpea genotype, and the interaction of the latter effect with sorghum genotype, were tested in the analysis of variables measured in the cowpea. The inclusion of the sole crop cowpea treatment may lead to heterogeneity of residual variances, so analyses confined to the intercrop cowpea treatments were also performed.

\section{RESULTS AND DISCUSSION}

The sorghum plant population densities in each cropping system were very close to the intended levels (Table 2). The main effects of sorghum genotype and of the presence of cowpea were significant for all canopy characteristics (Table 3) and there was a significant interaction between these effects for canopy width. However, there was no significant effect of cowpea genotype, nor any interaction of cowpea genotype with sorghum genotype. The canopy was higher and wider in the absence of cowpea, and consequently the light transmission was lower. The main effects for dry fodder and grain yield, and for most of the grain yield components, were significant (Table 4). The interaction of sorghum genotype with density was significant for grain yield and all its components, but not those for grain yield with cowpea presence and cowpea genotype, indicating that there is compensating variation in the components. The $\mathrm{F}$ values for weight per grain were consistently high, suggesting that this is the most responsive component. The interactions for fodder yield of sorghum genotype with density and cowpea presence were not significant, in

\section{Table 2. Actual sorghum plant population (plants $\mathrm{m}^{-2}$ ) and relative plant} populations as a percentage of intended population

\begin{tabular}{|c|c|c|c|c|c|c|c|c|}
\hline \multirow{3}{*}{$\begin{array}{l}\text { Sorghum } \\
\text { genotype }\end{array}$} & \multicolumn{8}{|c|}{ Cropping system } \\
\hline & \multicolumn{2}{|c|}{$\begin{array}{c}\text { Sole crop } \\
\text { density }\end{array}$} & \multicolumn{2}{|c|}{$\begin{array}{c}\text { Intercrop } \\
\text { density }\end{array}$} & \multicolumn{2}{|c|}{$\begin{array}{l}\text { Intercrop } \\
\text { with C } 152\end{array}$} & \multicolumn{2}{|c|}{$\begin{array}{l}\text { Intercrop } \\
\text { with GFC } 4\end{array}$} \\
\hline & Actual & Relative & Actual & Relative & Actual & Relative & Actual & Relative \\
\hline S 1006 & 18.9 & 105 & 7.6 & 127 & 6.1 & 102 & 6.2 & 103 \\
\hline CSH 5 & 19.2 & 107 & 7.6 & 127 & 6.4 & 107 & 6.1 & 102 \\
\hline $\mathrm{CSH} 6$ & 18.5 & 103 & 6.8 & 113 & 6.3 & 105 & 6.2 & 103 \\
\hline E 35-1 & 18.7 & 104 & 6.4 & 107 & 5.7 & 95 & 5.5 & 92 \\
\hline 2219 B & 20.3 & 113 & 6.9 & 115 & 6.3 & 105 & 5.9 & 98 \\
\hline
\end{tabular}


Table 3. Mean values for canopy variables in low density sole crop sorghum and in intercrops of sorghum with cowpea

\begin{tabular}{lccr} 
& & \multicolumn{2}{c}{ Cowpea present } \\
\cline { 3 - 4 } Sorghum genotype & Cowpea absent & C. 152 & GFC 4 \\
& Canopy height $(\mathrm{cm})$ & & \\
S 1006 & 100 & 80 & 83 \\
CSH 5 & 97 & 80 & 77 \\
CSH 6 & 113 & 93 & 100 \\
E 35-1 & 120 & 100 & 100 \\
2219 B & 73 & 67 & 67
\end{tabular}

$\mathrm{SE}$ of mean for comparisons with same sorghum genotype 3.8; different genotypes 2.7.

Canopy width $(\mathrm{cm})$

$\begin{array}{llll}\text { S } 1006 & 75 & 55 & 58 \\ \text { CSH 5 } & 67 & 53 & 62 \\ \text { CSH 6 } & 45 & 50 & 50 \\ \text { E } 35-1 & 70 & 60 & 62 \\ 2219 \text { B } & 52 & 28 & 33\end{array}$

SE of mean for comparisons with same sorghum genotype 3.0; different genotypes 11.1.

Light transmission (\%)

$\begin{array}{llll}\text { S } 1006 & 72 & 89 & 87 \\ \text { CSH 5 } & 76 & 82 & 87 \\ \text { CSH 6 } & 82 & 88 & 83 \\ \text { E } 35-1 & 73 & 81 & 73 \\ 2219 \text { B } & 87 & 93 & 94\end{array}$

SE of mean for comparisons with same sorghum genotype 2.4; different genotypes 3.0.

spite of the significant sorghum genotype $X$ cowpea presence term for canopy width.

There was no significant cowpea genotype $X$ sorghum genotype interaction for any recorded variable except weight per grain, indicating that the two contrasting cowpea genotypes had similar effects on the sorghum response. This suggests that if sorghum genotypes were screened with a single standard cowpea genotype, information on their response would be generally applicable. Similar results have been reported for intercrop systems of sorghum with millet (ICRISAT, 1980) and millet with groundnut (ICRISAT, 1981).

All sorghum genotypes grown as sole crops but at intercrop density yielded more than one third of the normal sole crop yield. Some gave more than one third of the normal yield when intercropped with $\mathrm{C} 152$ but all yielded less with GFC 4, especially the dwarf sorghum 2219 B. The pattern for dry fodder yield was similar except that the sorghum genotype E 35-1 yielded more than one third of the sole crop value in all cropping systems. These results indicate that the cowpea competed effectively with the sorghum for environmental resources such as soil moisture, nutrients and light, and that the cowpea genotype GFC 4 is more competitive than C 152, as would be expected from its growth habit.

Not all the yield components were affected in the same way by competition. 
Table 4. Mean values of variables measured in the sorghum, with land equivalent ratios (in brackets) for grain and dry fodder yields

\begin{tabular}{lccrr} 
& \multicolumn{2}{c}{ Sole crop } & \multicolumn{2}{c}{ Intercrop } \\
\cline { 2 - 3 } $\begin{array}{l}\text { Sorghum } \\
\text { genotype }\end{array}$ & $\begin{array}{l}\text { Normal } \\
\text { density }\end{array}$ & $\begin{array}{c}\text { Intercrop } \\
\text { density }\end{array}$ & With C 152 & With GFC 4 \\
S 1006 & 3063 & $1858(0.61)$ & $923(0.30)$ & $684(0.22)$ \\
CSH 5 & 3760 & $3181(0.85)$ & $1510(0.40)$ & $998(0.27)$ \\
CSH 6 & 4641 & $2560(0.55)$ & $1534(0.33)$ & $1012(0.22)$ \\
E 35-1 & 3665 & $2453(0.6)$ & $1232(0.34)$ & $1100(0.30)$ \\
2219 B & 3929 & $2385(0.61)$ & $1079(0.27)$ & $417(0.11)$
\end{tabular}

SE of mean for comparisons with same sorghum genotype 345 ; different genotypes 317 .

\begin{tabular}{|c|c|c|c|c|}
\hline \multicolumn{5}{|c|}{ Dry fodder yield $\left(\mathrm{kg} \mathrm{ha}^{-1}\right)$} \\
\hline S 1006 & 4764 & $3298(0.69)$ & $1980(0.42)$ & $1419(0.30)$ \\
\hline CSH 5 & 2945 & $2800(0.95)$ & $1585(0.54)$ & $874(0.30)$ \\
\hline $\mathrm{CSH} 6$ & 4811 & $2659(0.55)$ & $1763(0.37)$ & $859(0.18)$ \\
\hline E $35-1$ & 2882 & $2336(0.81)$ & $1582(0.55)$ & $1019(0.35)$ \\
\hline $2219 \mathrm{~B}$ & 3369 & $2177(0.65)$ & $1028(0.31)$ & $411(0.12)$ \\
\hline
\end{tabular}

$\mathrm{SE}$ of mean for comparisons with same sorghum genotype 179; different genotypes 255 .

\begin{tabular}{|c|c|c|c|c|}
\hline \multicolumn{5}{|c|}{ Heads plant ${ }^{-1}$} \\
\hline S 1006 & 0.94 & 1.01 & 0.98 & 0.93 \\
\hline $\mathrm{CSH} 5$ & 1.00 & 0.99 & 0.92 & 0.90 \\
\hline CSH 6 & 1.09 & 1.25 & 1.06 & 0.83 \\
\hline E $35-1$ & 0.93 & 0.98 & 1.00 & 0.89 \\
\hline $2219 \mathrm{~B}$ & 1.03 & 1.09 & 1.01 & 0.92 \\
\hline
\end{tabular}

$\mathrm{SE}$ of mean for comparisons with same sorghum genotype 0.041 ; different genotypes 0.041 .

\begin{tabular}{|c|c|c|c|c|}
\hline \multicolumn{5}{|c|}{ Grain head $^{-1}$} \\
\hline S 1006 & 733 & 959 & 590 & 557 \\
\hline $\mathrm{CSH} 5$ & 1190 & 2102 & 1262 & 958 \\
\hline CSH 6 & 953 & 1222 & 902 & 858 \\
\hline E $35-1$ & 792 & 1427 & 739 & 817 \\
\hline $2219 \mathrm{~B}$ & 973 & 1559 & 832 & 616 \\
\hline
\end{tabular}

$\mathrm{SE}$ of mean for comparisons with same sorghum genotype 105; different genotypes 113 .

\begin{tabular}{lcccc}
\multicolumn{5}{c}{ Weight grain $^{-1}(\mathrm{mg})$} \\
S 1006 & 24 & 25 & 26 & 22 \\
CSH 5 & 16 & 20 & 21 & 17 \\
CSH 6 & 24 & 25 & 26 & 22 \\
E 35-1 & 27 & 28 & 29 & 27 \\
2219 B & 19 & 21 & 20 & 13
\end{tabular}

$\mathrm{SE}$ of mean for comparisons with same sorghum genotype 0.68 ; different genotypes 0.75 .

The number of heads per plant of sorghum genotypes 2219 B and E 35-1 was equally reduced by GFC 4, the more competitive cowpea, but only the dwarf genotype $(2219 \mathrm{~B})$ showed a reduction in the number of grains per head. This genotype also showed a much greater reduction in weight per grain. This suggests that cowpea genotype has a greater influence on those yield components which are determined later in the developmental sequence, and in more extensive experiments this would probably have had a detectable effect on yield. At the least, therefore, any cowpea genotype used as a standard for sorgum evalua- 
Table 5. Cowpea grain and dry fodder yields

\begin{tabular}{|c|c|c|c|c|}
\hline \multirow[b]{2}{*}{ Sorghum genotype } & \multicolumn{2}{|c|}{$\begin{array}{l}\text { Grain yield } \\
\left(\mathrm{kg} \mathrm{ha}^{-1}\right)\end{array}$} & \multicolumn{2}{|c|}{$\begin{array}{l}\text { Dry fodder } \\
\text { yield }\left(\mathrm{kg} \mathrm{ha}^{-1}\right)\end{array}$} \\
\hline & C 152 & GFC 4 & C 152 & GFC 4 \\
\hline S 1006 & 1280 & 35 & 1339 & 2420 \\
\hline CSH 5 & 1119 & 34 & 906 & 1979 \\
\hline CSH 6 & 1421 & 24 & 1340 & 2048 \\
\hline E 35-1 & 1215 & 24 & 1021 & 2005 \\
\hline 2219 B & 1344 & 67 & 1288 & 2670 \\
\hline Sole cowpea & 2320 & 26 & 2424 & 3319 \\
\hline \multicolumn{5}{|l|}{$\mathrm{SE}$ of mean: } \\
\hline Comparisons with same sorghum genotype & \multicolumn{2}{|c|}{59} & \multicolumn{2}{|c|}{245} \\
\hline Different sorghum genotype & \multicolumn{2}{|c|}{63} & \multicolumn{2}{|c|}{254} \\
\hline
\end{tabular}

tion should be chosen with care but the use of a competitive cowpea genotype also emphasizes the unsuitability of dwarf sorghum genotypes for intercropping.

There were highly significant differences between cowpea genotypes for all variables except weight per grain, and for the sole crop:intercrop contrast and its interaction with cowpea genotype for grain yield, number of pods per plant and weight per grain. This indicates that each cowpea genotype responded in a specific way to the different cropping systems.

The intercrop sorghum genotype had no significant effects on the associated cowpea, contrary to the results of previous experiments (Galwey et al., 1986; de Queiroz, 1984). This may be because the other experiments were conducted in the rainy season whereas the present experiment was conducted in the postrainy season when the weather did not allow extensive sorghum canopy development. As a result the amount of light available to the cowpea, although significantly different between sorghum genotypes, was probably high enough not to limit growth. If such interactions were genuinely absent, cowpea genotypes could be screened for their performance in intercrop against a standard sorghum genotype, but this conclusion might not be valid in rainy-season environments.

The fodder cowpea GFC 4 gave an even smaller grain yield than anticipated (Table 5), probably because it is a variety adapted to the rainy season. However, its vegetative growth was good and its high yield of dry fodder was almost double that of $\mathrm{C} 152$ in corresponding treatments. It continued to grow and produce new leaves throughout the season but was harvested at the same time as the sorghum, when its few pods were ripe. A later harvest might have given even better dry fodder yields, and would probably be advantageous in agricultural practice, but would have tended to obscure any effects of the sorghum on the cowpea. Although GFC 4 had few pods per plant it was similar to C 152 for the other yield components.

\section{CONCLUSIONS}

In planning the evaluation of sorghum genotypes for intercropping with cowpea, it is necessary to decide at what stage to introduce the cowpea into the 
selection process, and this depends on the extent of the interaction between the cowpea and sorghum genotypes. No such interaction was evident in the sorghum dry fodder and grain yields, and though it was significant in the sorghum canopy width and yield components it was much smaller than the main effects. In rainy-season sowings, where sorghum canopy development is usually fuller and sorghum dominates the intercrop more completely, these interactions are likely to be even smaller than in this post-rainy season experiment.

The results indicate that in evaluating sorghum genotypes for intercropping with cowpea, the cowpea will probably not need to be included at early stages in the breeding programme. However, the significant interactions of sowing density with genotype in sorghum dry fodder and grain yield indicate that it will be important to grow the sorghum plants at intercrop density. This argument does not take account of the differing effects of sorghum genotypes on the cowpea, but this aspect would probably be considered at a later stage in the breeding programme. The absence of a significant sorghum genotype $X$ cowpea genotype interaction for any sorghum variable except weight per grain suggests that a single standard variety could probably be used when the cowpea is introduced into the evaluation of sorghum genotypes.

The absence of sorghum genotype $X$ cowpea genotype interaction for all the cowpea variables suggests that a standard sorghum variety could be used in the evaluation of different cowpea genotypes. However, it is likely that in rainy-season sowings fuller sorghum canopy development would result in such an interaction, in which case all combinations of promising sorghum and cowpea genotypes would have to be tested in the final stages of a breeding programme for either crop.

\section{REFERENCES}

De Wit, C. T. (1960). On competition. Verslag landbouwkundige Onderzoek 66(8):1-82.

Galwey, N. W., de Queiroz, M. A. \& Willey, R. W. (1986). Genotypic variation in the response of sorghum to intercropping with cowpea, and in the effect on the associated legume. Field Crops Research $14: 263-290$.

ICRISAT, (1980). Annual Report 1978/1979. Patancheru, India: International Crops Research Institute for the Semi-Arid Tropics.

ICRISAT, (1981). Annual Report 1979/1980. Patancheru, India: International Crops Research Institute for the Semi-Arid Tropics.

Queiroz, M. A. de (1984). Evaluation of sorghum genotypes for intercropping with cowpea. PhD thesis, University of Cambridge.

Ridgman, W. J. (1975). Experimentation in Biology. Glasgow and London: Blackie. 